\title{
Cinnamomum burmannii improves insulin serum level in the normal obese subjects: preliminary study
}

\author{
Hari Hendarto ${ }^{1}$, Flori R Sari ${ }^{2 *}$, Chris Adhyanto ${ }^{3}$ \\ ${ }^{1}$ Department of Internal Medicine, ${ }^{2}$ Department of Pharmacology, ${ }^{3}$ Department of \\ Biochemistry, Faculty of Medicine and Health Sciences, Syarif Hidayatullah Islamic State \\ University, Ciputat, Indonesia
}

DOI: http://dx.doi.org/10.19106/JMedSci005001201808

\begin{abstract}
Obesity is characterized with excessive accumulation of the body fat which occurs when the energy intake exceeds the expenditure. It is routinely associated with insulin resistance and hyperinsulinemia. Additionally, suppressing insulin level protects female mice from weight gaining. Cinnamon [Cinnamomum burmannii (Ness) Bl. Cortex] suppresses hyperinsulinemia condition in the type 2 diabetic rat suggesting the possible beneficial its role in the obesity. We aimed to investigate the effect of Cinnamon extract in the normal obese subjects. In this preliminary cross-over clinical trial, 24 normal obese subjects were recruited and divided randomly into two groups i.e. treatment and placebo. Two grams of the cinnamon extract were given twice daily for 56 days in the treatment group. Normal obese subjects given placebo were allocated as the placebo group. After the treatment, each of the group ran a one month run-in period, then the groups were crossovered for the next 56 days. Body mass index (BMI), insulin serum level, cholesterol and triglyceride plasma levels were measured at the beginning and at the end of the study. No diet restriction nor exercise intervention was given during the study. At the end of the study, BMI in the treatment group (58\%) were slightly reduced when compared to the placebo group (33\%), however, it was not significantly different $(p>0.05)$. Moreover, significantly reduction in the insulin serum level was observed in $63 \%$ subject in the treatment group compared to $33 \%$ subject in the placebo group $(p<0.05)$. Additionally, there were no significant differences of cholesterol and triglyceride plasma level observed in the both group. In conclusion, cinnamon extract may give beneficial role in the normal obese subjects by suppressing the serum insulin level. Further studies are required to elucidate the specific role of cinnamon in preventing weight gain.
\end{abstract}

\section{ABSTRAK}

Kegemukan ditandai dengan akumulasi berlebhan lemak tubuh yang terjadi ketika pemasukan energi melebihi pengeluaran. Kegemukan sering dikaitkan dengan resistensi insulin dan hiperinsulinemia. Selain itu terbukti penurunan kadar insulin mencegah kegemukan pada mencit. Kayu manis [Cinnamomun burmannii (Ness) BI. Cortex] dapat menekan kondisi hyperinsulinemia pada tikus diabetes tipe 2 dan diduga bermanfaat dalam mencegah kegemukan. Penelitian ini bertujuan untuk mengkaji efek ekstrak kayu putih pada sukarelawan sehat. Pada uji klinik awal dengan rancangan silang ini, 24 sukarelawan dengan kegemukan normal yang dilibatkan penelitian dibagi acak menjadi dua kelompok yaitu kelompok perlakuan dan kontrol. Dua gram ekstrak kayu putih diberikan

\footnotetext{
* corresponding author : florirsari@uinjkt.ac.id
} 
dua kali sehari selama 56 hari pada kelompok perlakuan, sedangkan kelompok kontrol diberi plasebo. Setelah perlakuan, masing-masing kelompok diberi latihan (lari) setiap hari selama satu bulan, kemudian masing-masing kelompok disilang untuk mendapatkan perlakuan atau kontrol selama 56 hari berikutnya. Indeks massa tubuh (IMT), kadar insulin serum, kadar kolesterol dan trigliserit plasma diukur di awal dan akhir penelitian. Tidak ada pembatasan dan juga latihan diberikan selama penelitian. Di akhir penelitian, IMT kelompok perlakuan $(58 \%)$ sedikit turun dibandingkan kelompok plasebo $(33 \%)$. Namun demikian perbedaan ini tidak bermakna $(p>0,05)$. Selanjutnya, penurunan kadar insulin serum secara nyata terjadi pada $63 \%$ sukarelawan pada kelompok perlakuan dibandingkan $33 \%$ pada kelompok plasebo $(p<0,05)$. Tidak ada perbedaan nyata kadar kolesterol dan trigliserida plasma antara kedua kelompok. Dapat disimpulkan, ekstrak kayu manis bermanfaat bagi subjek dengan kegemukan normal melalui perannya dalam menurunkan kadar insulin serum. Penelitian lanjutan diperlukan untuk mengkaji peran spesifik kayu manis dalam mencegah kegemukan.

Keywords : Cinnamomum burmannii - obesity - insulin - body mass index - lipid profile

\section{INTRODUCTION}

Obesity is a metabolic disorder characterized with excessive expansion of adipose tissue due to imbalances between nutrient intake and energetic activity. ${ }^{1}$ Obesity has remarkably increased worldwide and leads to significant morbidity and mortality related to cardiovascular disease, metabolic syndrome, type 2 diabetes, hypertension, degenerative joint disease and some kinds of cancer. It is affecting 33\% of adults in the United States and becomes the most common public health problems. $^{2}$ Some strategies have been proposed to reduce enormous body weight in the obese state by inhibiting fat absorption in the gut or supressing appetite in the brain. Recently, it is found that insulin resistance and hyperinsulinemia are the key characteristics of obesity which contributes to its further complication on health. ${ }^{3-5}$ In the obese state, compensatory rise of insulin due to hyperglycemia, may lead to insulin resistance. ${ }^{6}$ Furthermore, hyperinsulinemia may promote obesity, resulting in a vicious cycle between obesity, insulin resistance and hyperinsulinemia. ${ }^{6-11}$ It has been reported that attenuating hyperinsulinemia in the experimental young female mice provides protection against obesity and reducing insulin secretion may promote weight loss in obese adults with insulin hypersecretion. ${ }^{6,12,13}$ Conclusively, reducing insulin secretion may have beneficial role in the strategy of obesity treatment.

Cinnamomum burmannii (Ness) BI. Cortex, widely known in Indonesia as cinnamon or kayu manis, cassia in Padang and Batavia, is an endogenous plant that has been traditionally used as spices, herb and medicine. ${ }^{14}$ It is currently marketed as a supplemental herbal for diabetes mellitus, dyslipidaemia and glucose intolerance since experimental. Clinical evidence showed that cinnamon has a role as insulin sensitizing agent. In 3T3L1 adipocyte tissue, cinnamon extract stimulates glucose uptake and glycogen synthesis and further activates glycogen synthase. ${ }^{15}$ Additionally, cinnamon bioactive component stimulates enzymatic reaction of phosphorylation and dephosphorylation, confirming its role as an insulin mimetic. ${ }^{16}$ Furthermore, cinnamon extract may decrease the blood glucose level and stimulate glucose uptake in the experimental type 1 diabetic 
rat or type 2 diabetic mice. ${ }^{17-20}$ Recently, evidences have been reported that cinnamon bioactive components, proanthocyanidin and cinnamaldehyde, could improve the formation of pancreatic islet polypeptide and suppress hyperinsulinemia condition in the type 2 diabetic rat. ${ }^{21-23}$

In the clinical setting, daily consumption of 1,3 or $6 \mathrm{~g}$ cinnamon supplement reduced the blood glucose level up to $29 \%$ in the type 2 diabetic patients ${ }^{24}$ and routine consumption of $3 \mathrm{~g}$ cinnamon supplement in eight weeks reduced body weight and body mass index (BMI) in type 2 diabetic patients. ${ }^{25}$ These mechanisms may be mediated through the role of cinnamon in improving the body composition and attenuating lipogenic processes in the liver and adipose tissue. ${ }^{26}$ Conversely, another study reported that 4 month treatment with a dietary supplement containing cinnamon, chromium and carnosine decreased fasting plasma glucose (FPG) and increased fat-free mass. However, there was no different with placebo with respect to body weight and BMI in overweight or obese prediabetic subjects. ${ }^{27}$ Despite our significant understanding of the role of cinnamon in the improvement of diabetes, the roles of cinnamon in obesity and its insulin regulation are largely unknown. In the present study, we investigated the effect of cinnamon extract in the normal obese subjects.

\section{MATERIALS AND METHODS}

\section{Cinnamon burmannii extract}

Cinnamon extract was prepared in a capsules preparation by UD Rachma Sari and certified by the National Agency of Drug and Food Control, Republic of Indonesia (TR 123365801). Each cinnamon capsules contained two $g$ of cinnamon extract. Placebo capsules were packaged as the same as the cinnamon capsule. Both the cinnamon and placebo capsules were packaged in plastic bag containing 14 capsules (two capsules of two $g$ for 7 days) and prepared for distribution of the subjects. Subjects received one capsule twice daily (with the total dose of $4 \mathrm{~g} /$ day) for 56 days. The dose were decided based on two previous studies using dose range from 1 - 6 g/day. ${ }^{24,25}$ Subjects were evaluated every 7 days for supplement compliance until the end of the study. Compliance was monitored by capsule count, subjects interview and daily diary analysis.

\section{Design}

The design of this preliminary study was randomized cross-over clinical trial study. The study was divided in two phase, in each of the phase every subject received 56 days of capsules (treatment or placebo). Subjects were recruited and allocated randomly into two groups i.e. treatment and placebo. Cinnamon capsules were given for 56 days in normal obese subjects in the treatment group. Another group of normal obese subjects were given placebo as the placebo group. After finishing 56 days treatment, each of the group ran a one month run-in period, and then the groups were cross-overed for the next 56 days. Subjects were not informed which treatment they have received until the end of the study.

\section{Study population}

This study was conducted in the Faculty of Medicine and Health Science, Islamic State University and was approved by the Ethics Committee and Human Studies Review Board of Faculty of Medicine and Health Science, Islamic State University. Selection criteria for the study were adult normal obese subjects with $\mathrm{BMI} \geq 23 \mathrm{~kg} / \mathrm{m}^{2}$ and age ranged from 18 to 70 year old. Subjects were excluded from the study if they have: degenerative 
disease (hypertension, diabetes mellitus, coronary artery disease, atherosclerosis), cancer, scheduled diet process, pregnancy, breastfeeding, long term pharmacotherapy (chemotherapy, corticosteroid, insuling sensitizing agent, anti-hypertension and anticholesterol).

\section{Follow up and outcome measures}

Body mass index were measured by dividing body weight $(\mathrm{kg})$ with squared of body height $(\mathrm{m})$. The serum insulin level was measured by ELISA technique using ELISA insulin kit (Calbiotech, Spring Valley, CA, USA). In brief, subjects sera were incubated for 60 minutes with insulin enzyme conjugate, washed, added with TMB substrat for 15 min. After the addition of stop solution, sera were analyzed by ELISA reader. The plasma cholesterol level was measured by cholesterol esterase/cholesterol oxidase technique using cholesterol kit (Sclavo Diagnostics, Siena, Italy). The plasma triglyceride level was measured by triglyceride kit (Diasys Diagnostic System, Holzheim, Germany). Subjects were followed up every 7 days, however, outcome measures were conducted only on day 1 and day 56 . At each visits, the occurrence of study outcomes was ascertained according to the intention-to-treat principle.

\section{Data analysis}

The variable of this study were the BMI, the serum insulin level, the plasma cholesterol and tryglyceride levels. All variable data from the recruited patients were included in the analyses. Comparison among groups was performed using one-way analysis of variance (ANOVA) or student's t-test, wherever applicable. A p <0.05 was considered as statistically significant.

\section{RESULTS}

\section{Baseline characteristics}

The characteristics of subjects were summarized in TABLE 1 . Twenty four normal obese subjects were recruited and followed up every 7 days until the end of the study. None of them were dropped out during the study. No significant differences of BMI, insulin serum level, cholesterol plasma level and triglyceride plasma level were observed among the groups $(\mathrm{p}>0.05)$.

TABLE 1. Baseline characteristics (mean $\pm \mathrm{SD}$ ) between placebo and treatment group

\begin{tabular}{lccc}
\hline \multicolumn{1}{c}{ Variablle } & $\begin{array}{c}\text { Placebo group } \\
\mathbf{n = 2 4}\end{array}$ & $\begin{array}{c}\text { Treatment group } \\
\mathbf{n = 2 4}\end{array}$ & $\mathbf{p}$ \\
\hline Male & 12 & 12 & \\
Female & 12 & 12 & \\
Body Mass Index $\left(\mathrm{kg} / \mathrm{m}^{2}\right)$ & $28.9 \pm 4.8$ & $28.9 \pm 5.0$ & 0.9 \\
Insulin $(\mathrm{mg} / \mathrm{dL})$ & $23.6 \pm 22.2$ & $19.4 \pm 14.3$ & 0.4 \\
Cholesterol $(\mathrm{mg} / \mathrm{dL})$ & $164 \pm 41$ & $171 \pm 27$ & 0.5 \\
Triglyceride $(\mathrm{mg} / \mathrm{dL})$ & $121 \pm 70$ & $111 \pm 66$ & 0.6 \\
\hline
\end{tabular}

\section{Effect of cinnamon on BMI and insulin serum level}

The effect of cinnamon extract on the BMI and the serum insulin level were summarized in TABLE 2. There was no significantly different on the BMI observed between the placebo and the treatment group, however, slight decrease of 0.1 point was observed. 
The serum insulin level increased 8.2 point, however, it was not significantly different. The serum insulin was decreased in 8 subjects received placebo $(33 \%)$ and increased in the rest of the subjects. Conversely, cinnamon extract decreased the serum insulin level in 15 subjects $(63 \%)$. Briefly, the serum insulin level was significantly higher on day 1 (19.4 $\pm 14.3 \mathrm{mg} / \mathrm{dL})$ than on day $56(16.6 \pm 16.4$ $\mathrm{mg} / \mathrm{dL})$ in the treatment group $(\mathrm{p}<0.05)$. No significantly different in plasma cholesterol and triglyceride levels of the both group on day 1 and on day 56 were observed $(\mathrm{p}>0.05)$.

TABLE 2. Effect of cinnamon extract on BMI, serum insulin level, plasma cholesterol and triglyceride levels after 56 days of treatment

\begin{tabular}{lccccc}
\hline \multirow{2}{*}{\multicolumn{1}{c}{ Variable }} & \multicolumn{2}{c}{ Placebo } & \multicolumn{2}{c}{ Treatment } & p \\
\cline { 2 - 5 } & Day 1 & Day 56 & Day 1 & Day 56 & \\
\hline Body Mass Index $\left(\mathrm{kg} / \mathrm{m}^{2}\right)$ & $28.9 \pm 4.8$ & $28.9 \pm 4.9$ & $28.9 \pm 5.0$ & $28.8 \pm 4.7$ & 0.94 \\
Insulin (mg/dL) & $23.6 \pm 22.2$ & $31.8 \pm 27.3$ & $19.4 \pm 14.3$ & $16.6 \pm 16.4$ & 0.02 \\
Cholesterol (mg/dL) & $164 \pm 41$ & $169 \pm 18$ & $171 \pm 27$ & $165 \pm 14$ & 0.47 \\
Triglyceride (mg/dL) & $121 \pm 70$ & $135 \pm 84$ & $111 \pm 66$ & $109 \pm 76$ & 0.26 \\
\hline
\end{tabular}

\section{DISCUSSION}

The salient finding of our research are: (1) cinnamon extract decreased the level of insulin serum in $63 \%$ subjects and (2) cinnamon extract decreased significantly the level of insulin serum in 56 days compared to the placebo. In the obese state, insulin may elevate as a compensatory mechanism due to chronic hyperglycemia. Additionally, the chronic elevation of insulin serum level may decrease the insulin responsiveness in the tissues and lead to insulin resistance. ${ }^{6}$ Chronic hyperglycemia and hyperinsulinemia work reciprocally and worsen the obese state, resulting in a vicious cycle between obesity, insulin resistance and hyperinsulinemia. ${ }^{6-11}$ Clinical and experimental evidence have shown that attenuating hyperinsulinemia not only promote weight loss but also provide protection against obesity. ${ }^{6,12,13}$

Cinnamon has been widely used as spices, herb and traditional medicine. It has been reported that cinnamon exerts potent anti-diabetic effects through its role as insulin mimetic and insulin sensitisizing agent. ${ }^{15-20}$ Moreover, cinnamon gives beneficial role in the type 2 diabetic patient by reducing significantly plasma blood glucose level. ${ }^{24,25}$ We have shown in this study that cinnamon extract decreased the level of insulin serum in $63 \%$ normal obese subjects and it decreased significantly the level of insulin serum in 56 days of study. Our results were consistent with the previous finding that cinnamon component of proanthocyanidin improves the formation of pancreatic islet polypeptide and its cinnamaldehyde suppresses hyperinsulinemia condition. ${ }^{21-23}$

Additionally, cinnamon extract decreased the BMI of the subjects, however, it was not significantly different. Previous study has shown that routine consumption of $3 \mathrm{~g}$ cinnamon supplement in eight weeks reduced body weight and BMI in type 2 diabetic patient. ${ }^{25}$ These mechanisms may be mediated through the role of cinnamon in improving the body composition and attenuating lipogenic processes in the liver and adipose tissue. ${ }^{26}$ 
Another study reported that 4 month treatment with a dietary supplement containing cinnamon, chromium and carnosine decreased fasting plasma glucose (FPG) and increased fat-free mass, however, there was no difference versus placebo with respect to body weight and BMI in overweight or obese pre-diabetic subjects. ${ }^{27}$ We have concluded that negative result of cinnamon on the BMI in our study may be due to differences in the dose regiment and duration. We should give the proper regiment with longer treatment to evaluate the long-term effect of cinnamon in preventing the weight gain.

Some strategies have been proposed to reduce excessive body weight in the obese state by inhibiting fat absorption in the gut or suppressing appetite in the brain. ${ }^{2}$ Recently, it is found that insulin resistance and hyperinsulinemia are the key characteristics of obesity which contributes to its further complication on health. ${ }^{3-5}$ Consistent with the previous finding, we have shown that cinnamon may give beneficial role in obesity not only by increasing insulin sensitivity but also by attenuating hyperinsulinemia condition.

\section{CONCLUSIONS}

Cinnamon extract may give beneficial role in the normal obese subjects by suppressing the serum insulin level. Further studies are required to elucidate the specific role of cinnamon in preventing weight gain.

\section{ACKNOWLEDGEMENTS}

Authors would like to thank subjects who participated in this study.

\section{REFERENCES}

1. Tanti JF, Ceppo F, Jager J, Berthou F. Implication of inflammatory signaling pathways in obesity-induced insulin resistance. Front Endocrinol (Lausanne) 2012; 3:181. http://dx.doi.org/10.3389/fendo.2012.00181

2. Anonym. Clinical guidelines on the identification, evaluation, and treatment of overweight and obesity in adults--the evidence report. National Institutes of Health. Obes Res 1998; 6(Suppl 2):51-209.

3. Kahn BB, Flier JS. Obesity and insulin resistance. J Clin Invest 2000; 106(4):473-81. http://dx.doi.org/10.1172/JCI10842

4. Prentki M, Nolan CJ. Islet $\beta$ cell failure in type 2 diabetes. J Clin Invest 2006; 116(7):1802-12. http://dx.doi.org/10.1172/JCI29103

5. Taniguchi CM, Emanuelli B, Kahn CR. Critical nodes in signalling pathways: insights into insulin action. Nat Rev Mol Cell Biol 2006; 7(2):85-96. http://dx.doi.org/10.1038/nrm1837

6. Templeman NM, Clee SM, Johnson JD. Supression of hyperinsulinaemia in growing female mice provides long-term protection against obesity. Diabetologia 2015; 58(10):2392-402.

http://dx.doi.org/10.1007/s00125-015-3676-7

7. Genuth SM, Przybylski RJ, Rosenberg DM. Insulin resistance in genetically obese, hyperglycemic mice. Endocrinology 1971; 88(5):1230-8.

http://dx.doi.org/10.1210/ endo-88-5-1230

8. Odeleye OE, de Courten M, Pettitt DJ, Ravussin E. Fasting hyperinsulinemia is a predictor of increased body weight gain and obesity in Pima Indian children. Diabetes 1997; 46(8):1341-5.

http://dx.doi.org/10.2337/diabetes.46.8.1341

9. Sigal RJ, El-Hashimy M, Martin BC, Soeldner JS, Krolewski AS, Warram JH. Acute postchallenge hyperinsulinemia predicts weight gain: a prospective study. Diabetes 1997; 46(6):1025-9.

http://dx.doi.org/10.2337/diabetes.46.6.1025 
10. Ishikawa $\mathrm{M}$, Pruneda ML, AdamsHuet B, Raskin P. Obesity-independent hyperinsulinemia in nondiabetic first-degree relatives of individuals with type 2 diabetes. Diabetes 1998; 47(5):788-92. http://dx.doi.org/10.2337/diabetes.47.5.788

11. Mehran AE, Templeman NM, Brigidi GS, Lim $\mathrm{GE}$, Chu KY, Hu X, et al. Hyperinsulinemia drives diet-induced obesity independently of brain insulin production. Cell Metab 2012; 16(6):723-37.

http://dx.doi.org/10.1016/j.cmet.2012.10.019

12. Alemzadeh R, Langley G, Upchurch L, Smith P, Slonim AE. Beneficial effect of diazoxide in obese hyperinsulinemic adults. J Clin Endocrinol Metab 1998; 83(6):1911-5. http://dx.doi.org/10.1210/jcem.83.6.4852

13 Lustig RH, Greenway F, Velasquez-Mieyer P, Heimburger D, Schumacher D, Smith D, et al. A multicenter, randomized, doubleblind, placebo-controlled, dose-finding trial of a long-acting formulation of octreotide in promoting weight loss in obese adults with insulin hypersecretion. Int J Obes 2005; 30(2):331-41.

http://dx.doi.org/10.1038/ sj.ijo.0803074

14. Widiyanti T. Teknik Perbanyakan Kayu Manis (Cinnamomum sp.) Secara Generatif. Balai Besar Perbenihan dan Proteksi Tanaman Perkebunan Surabaya. 2012.

15. Jarvill-Taylor KJ, Anderson RA, Graves DJ. A hydroxychalcone derived from cinnamon functions as a mimetic for insulin in 3T3-L1 adipocytes. J Am Coll Nutr 2001; 20(4):327-36. http://dx.doi.org/10.1080/07315724.2001.10 719053

16. Imparl-Radosevich J, Deas S, Polansky MM, Baedke DA, Ingebritsen TS, Anderson RA, et al. Regulation of PTP-1 and insulin receptor kinase by fractions from cinnamon: implications for cinnamon regulation of insulin signalling. Horm Res 1998; 50(3):177-82. http://dx.doi.org/10.1159/000023270
17. Hendarto H, Sari FR, Muqorrobin A, et al. Cinnamomum cassia extract improves blood glucose and lipid profile in aloxan-induced diabetic rat. Asian J Microbiol Biotechnol Environ Sci 2015; 17:409-14.

18. Qin B, Nagasaki M, Ren M, Bajotto G, Oshida Y, Sato Y. Cinnamon extract (traditional herb) potentiates in vivo insulin-regulated glucose utilization via enhancing insulin signaling in rats. Diabetes Res Clin Pract 2003; 62(3):13948.

http://dx.doi.org/10.1016/S01688227(03)00173-6

19. Subash Babu P, Prabuseenivasan S, Ignacimuthu S. Cinnamaldehyde--a potential antidiabetic agent. Phytomedicine 2007; 14(1):15-22. http://dx.doi.org/10.1016/j.phymed.2006.11. 005

20. Kim SH, Hyun SH, Choung SY. Anti-diabetic effect of cinnamon extract on blood glucose in $\mathrm{db} / \mathrm{db}$ mice. J Ethnopharmacol 2006; 104(12):119-23. http://dx.doi.org/10.1016/j.jep.2005.08.059

21. Jiao L, Zhang X, Huang L, Gong H, Cheng B, Sun Y, et al. Proanthocyanidins are the major anti-diabetic components of cinnamon water extract. Food Chem Toxicol 2013; 56:398-405. http://dx.doi.org/10.1016/j.fct.2013.02.049

22. Chen L, Sun P, Wang T, Chen K, Jia Q, Wang $\mathrm{H}$, Li Y. Diverse mechanisms of antidiabetic effects of the different procyanidin oligomer types of two different cinnamon species on $\mathrm{db} / \mathrm{db}$ mice. J Agric Food Chem 2012; 60(36):9144-50. http://dx.doi.org/10.1021/jf3024535

23. Li J, Liu T, Wang L, Guo X, Xu T, Wu L, et al. Antihyperglycemic and antihyperlipidemic action of cinnamaldehyde in C57BLKS/J db/ db mice. J Tradit Chin Med 2012; 32(3):44652 .

https://doi.org/10.1016/S02546272(13)60053-9 
24. Khan A, Safdar M, Ali Khan MM, Khattak $\mathrm{KN}$, Anderson RA. Cinnamon improves glucose and lipids of people with type 2 diabetes. Diabetes Care 2003; 26(13):3215-8. https://doi.org/10.2337/diacare.26.12.3215

25. Vafa M, Mohammadi F, Shidfar F, Sormaghi MS, Heidari I, Golestan B, et al. Effects of cinnamon consumption on glycemic status, lipid profile and body composition in type 2 diabetic patients. Int J Prev Med 2012; 3(8):531-6.

26. Lopes BP, Gaique TG, Souza LL, Paula GS, Kluck GE, Atella GC, et al. Cinnamon extract improves the body composition and attenuates lipogenic processes in the liver and adipose tissue of rats. Food Funct 2015; 6(10):3257-65.

http://dx.doi.org/10.1039/c5fo00569h

27. Liu Y, Cotillard A, Vatier C, Bastard JP, Fellahi S, Stévant M, et al. A Dietary supplement containing cinnamon, chromium and carnosine decreases fasting plasma glucose and increases lean mass in overweight or obese pre-diabetic subjects: a randomized, placebo-controlled trial. PLoS One 2015; 10(9):0138646.

http://dx.doi.org/10.1371/journal. pone. 0138646 